\title{
Cultural Wisdom of Minangkabau Ethnic Community for Local - Global Virtual Identity
}

\section{Elda Franzia}

\author{
Visual Communication Design, Faculty of Art and Design, Trisakti University \\ Email: eldafranzia@gmail.com
}

\section{Doi:10.5901/mjss.2017.v8n1p325}

\begin{abstract}
The development of digital technology is extending the opportunity to create a new identity of society. Digital technology enables cultural experience across boundaries, to new places of virtual world. Virtual identity functions as main differentiator of personal account in social media. It represents a personal being in virtual world. It also functions as a sign to culture and life's value of the person behind an account. This paper discussed about the virtual identity use by the Minangkabau ethnic's people in Facebook. Iconic artifacts of Minangkabau use in profile picture of the social media. Those artifacts valued with Minangkabau's cultural wisdom. The approach use for this research is cultural studies, with the semiotic method use to search the relation between the image and the cultural wisdom representation of Minangkabau. The visual data collected by capturing profile picture in Facebook. The image analyzed as everyday symbolic and expressive practice and form of Minangkabau ethnic's people. The picture is the iconic sign resembles to its conceptual object in certain ways. The result is the understanding of how profile picture function as indirect visual communication of local - global identity of Minangkabau ethnic people. The message convey in virtual identity relates the account and others in cyberspace.
\end{abstract}

Keywords: virtual, identity, culture, wisdom, Minangkabau

\section{Introduction}

The fast changing world nowadays has constructed by the development of digital technology. Digital innovation of information and technology provide us with World Wide Web. People connect to each other through the net in cyberspace. Cyberspace becomes place to connect people from all over the world without time and place boundaries. Digital technology enables cultural experience across boundaries, to new places of virtual world.

Indonesia as a developing country has impacted by the global changing world. The development of internet users in Indonesia is $15.8 \%$ in the last 3 years (http:// www.internetsociety.org/map/global-internet-report/). Jakarta, the capital city of Indonesia, has become the social media capital of the world (http://socialmemos.com/social-media-statistics-forindonesia/). The top ranks social media are Facebook, Twitter, Linkedln, YouTube, Instagram.

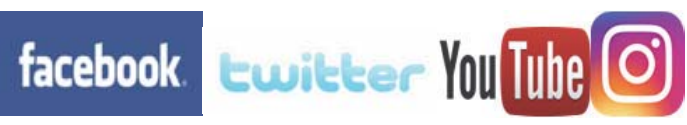

Figure 1. The Tops Ranks Social Media in Indonesia

Source: www.facebook.com; www.twitter.com; www.youtube.com; www.instagram.com

Facebook is still the most popular social media in Indonesia. The Facebook user in Jakarta is more than 11 million. Another 29 million Indonesian users on Twitter and 2.4\% tweet post of 10.6 billion tweets worldwide are from Jakarta. Jakarta is a melting pot of people from many ethnics in Indonesia. As a capital city of Indonesia, Jakarta is a picture of global culture in Indonesia. One of the ethnic that has been part of the digital lifestyle is Minangkabau ethnic people.

\section{Minangkabau Ethnic}

Minangkabau is one of the ethnic groups in Indonesia. This ethnic group is known for its dynamic culture. The ethnic group is originated from West Sumatra and they are used to travel around the country to seek for a better life. This tradition called merantau. It is a common activity for young people to search for better living, higher education, and life's experiences. Through the activity of merantau, the young people of Minangkabau carry their culture and tradition to the 
new land.

Tradition is the basis of Minangkabau culture. They have traditional proverb that say, Adat Basandi Syarak; Syarak Basandi Kitabullah. It means that their culture based on their religion (Islam) and their religion based on the Holy Qur'an. The religion is the main principle of the culture of Minangkabau. It became the cultural identity of Minangkabau people. The cultural identity has been declared in Minangkabau Cultural Congress in year 2010. Minangkabau community has a unique characteristic of tradition and iconic artifact such as in wedding, clothing, and housing.

The Minangkabau ethnic people are expanding the culture of merantau in its meaning. Merantau is originated means the movement of Minangkabau people from West Sumatra to other region in Indonesia, or other countries. After the existence of cyberspace, merantau also means the movement of Minangkabau people to cyberspace through the World Wide Web.

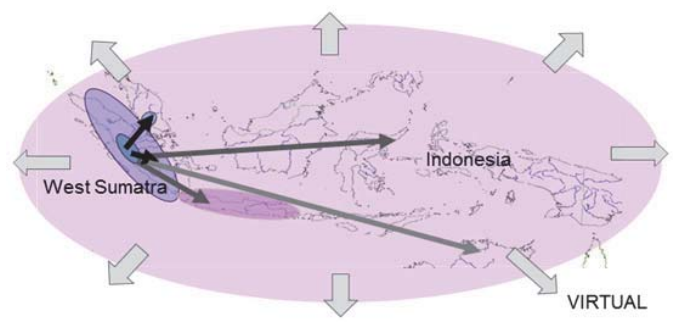

Figure 2. The Culture of Merantau

Merantau culture spread the Minangkabau people from their originated hometown, West Sumatera, to other islands in Indonesia and also to other country. After the existing of virtual world, the Minangkabau ethnic people also spread their identity to cyberspace. Minangkabau ethnic people exist in cyberspace as individual or groups. In social media they are represented by the profile picture. The profile picture is the virtual identity of an account in social media such as Facebook, Twitter, YouTube, and Instagram. The ethnic's characteristic are recognized from the form and colors in profile picture.

\section{Method}

The approach of this research is cultural studies. Cultural studies is a method that used to understanding the human tendencies in cultural changes, including to create the personal identity in cyberspace. Cultural studies is discursive formation, a cluster of ideas, images and practices, which provide ways of talking, forms of knowledge and practice (Hall, 1997; Barker, 2012: 5). Identity and representation is the main aspect of cultural studies. Cultural studies explore the cultural changes and read it as the texts of life. In order to understand the text of life, cultural studies use other method such as visual analysis and semiotic method.

Visual analysis method is used to give understanding the visual image as cultural text. Visual analysis method is needed to analyze the elements of image. The image contains symbols and meanings. The semiotic method use to search the relation between image and the cultural wisdom representation of Minangkabau.

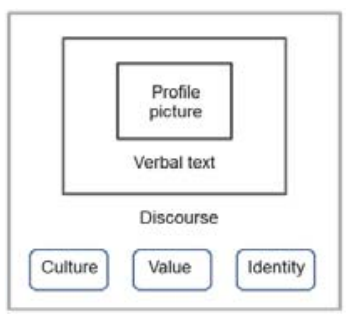

Figure 3. Semiotic Method in Cultural Studies 
Profile picture is the object of analysis. Profile picture as the visual image consist of composition of form, object, colors, and spatial organization. Profile picture in social media are also accompanied by the verbal text. Verbal text is usually the name of the account. Profile picture is the representation of the verbal text. The form, object, colors, and spatial organization worked as a sign to convey the meaning of Minangkabau cultural identity.

The images as visual data are collected by capturing profile picture in Facebook. The Minangkabau cultural symbol and identity collected from the literature study. The image analyzed as everyday symbolic and expressive practice and form of Minangkabau ethnic's people. Profile picture as sample fulfilled the criteria which are: (a) The image is the representation of Minangkabau people's account, (b) The image consists of Minangkabau's visual characteristic, and (c) The image has variety of objects.

\section{Analysis}

Cyberspace has created new personal of individuality. In cyberspace, a person constructed a second self. The computer offered new models of mind and new medium of human's ideas and fantasies (Turkle, 1995: 9). Virtual identity is a definition of self and the representation of self in cyberspace. In personal context, virtual identity is a second persona of the person behind an account. It is a self definition of the account. In social context, virtual identity is a differentiation of another account to whom the person is being related. Through virtual identity, a person has existence in the global cyberspace.

On the other hand, in a real world there is a person's nature identity. A person's nature identity includes race and ethnicity. Ethnicity is both a physical fact and a cultural creation from a certain ethnic community. It refers to a sense of group affiliation based on a distinct heritage of worldview as people. Ethnicity is a cultural concept centered on the sharing norms, values, beliefs, cultural symbols and practices (Barker, 2012: 255). The formation of ethnic groups relies on shared cultural signifiers that have developed under specific historical, social, and political contexts.

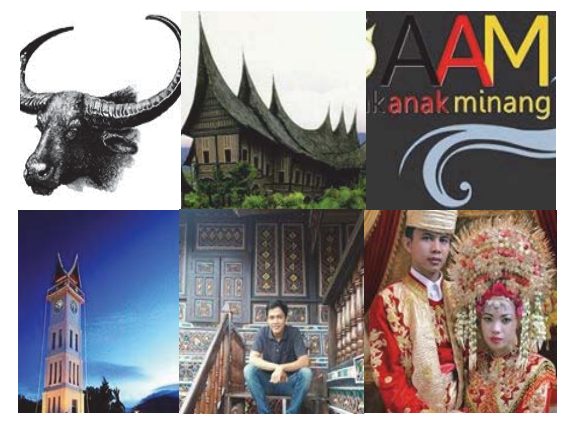

Figure 4. Examples of Minangkabau's Profile Picture

In social media such as Facebook, Twitter, YouTube, Instagram, profile picture of Minangkabau ethnic can be recognized from the commonly used colors and form. The traditional colors of Minangkabau is yellow, red, and black. In traditional form, the three colors is the colors of marawa. Marawa is the traditional banner in Minangkabau ethnic culture that use in various event of Minangkabau people as the symbol of cultural territory of Minangkabau. Each color is a symbolic meaning of the homeland country (luhak nan tigo) which is Luhak Tanah Datar, Luhak Agam, and Luhak Lima Puluh Koto (Amir, 2006: xxi). It also symbolizes the greatness, braveness, and the resistance and wisdom. The three colors commonly showed in traditional banner, traditional clothes, and traditional motifs in crafts.

Another iconic artifact showed in profile picture of Minangkabau ethnic people's account is traditional house called Rumah Gadang or means big house. The traditional house has a unique form. It is a large rectangular house with spire curved roof structure with multiple gables and upsweeping ridges, formed like the horns of buffalo. Buffalo horn is often associated with stories of the winning of the Minang's buffalo in war to Javanese people. It has been told in traditional stories of Minangkabau or Tambo Minangkabau (Amir, 2006: 150). It is also become the history of the name Minangkabau. Minang or menang means win and kabau or kerbau means buffalo.

The spire buffalo horn's roof symbolized the relation to God and nature. God and nature are important in Minangkabau culture as the traditional proverb says that their culture based on their religion and the nature is the teacher of human's life. 


\section{Results and Discussion}

Each samples of Minangkabau's profile picture contains elements of image which has meanings in cultural context and values. The specific forms and colors captured in elements of the image above.

\begin{tabular}{|c|c|c|}
\hline Image & Profile Picture & Cultural Wisdom \\
\hline Buffalo horn & & Wisdom and witty character of Minangkabau people. \\
\hline Steep upright roof in Rumah Gadang and tower & & Relation and worship to God. \\
\hline Three colors: Yellow, Red, Black & & $\begin{array}{l}\text { The greatness, braveness, and the resistance and } \\
\text { wisdom. }\end{array}$ \\
\hline Curved line & & The dynamicity of Minangkabau people and culture. \\
\hline Motifs of traditional house & & Relation to nature and the value to learn from nature. \\
\hline Gold platted accessories in traditional clothes & & The greatness of Minangkabau people and culture. \\
\hline Head cover in traditional clothes & & The obedience of the Islamic rules and norms. \\
\hline
\end{tabular}

Tabel 1. Relation between Image and Cultural Wisdom of Minangkabau 


\section{Conclusion}

Minangkabau ethnic people are part of global culture community. The dynamicity characteristic of Minangkabau ethnic has allowed people of Minangkabau to going to another region outside their local hometown in West Sumatra, Indonesia and abroad. They also involved in cyber community in cyberspace. In cyberspace, they represented by the profile picture in social media such as Facebook. Their virtual identity is a second persona and become the differentiation of another account to whom the person is being related. Through virtual identity, the Minangkabau ethnic people mark their existence in the global culture.

Samples of profile pictures showed elements of image represent cultural wisdom of Minangkabau ethnic community. The cultural wisdom is embraced in local community but going global as they are using in the global society's communication. The value of cultural identity Adat Basandi Syarak, Syarak Basandi Kitabullah has being understood in modern life. Obedience of the Islamic rules and norms showed in the traditional clothes and head covers in profile picture. The relation to God and nature showed through the form and motifs in traditional house. The greatness, braveness, and wisdom of Minangkabau ethnic conveyed through the colors used in images of profile picture. The dynamicity of Minangkabau has been showed by the using of traditional clothes and traditional house as the profile picture of social media. All the elements of image function as visual communication. Therefore, the profile picture is an indirect visual communication of local - global identity of Minangkabau ethnic people.

\section{Reference}

Amir, M.S., 2006. Adat Minangkabau, Pola dan Tujuan Hidup Orang Minang, Cetakan Kelima, Jakarta: PT Mutiara Sumber Widya. Barker, Chris, 2012. Cultural Studies, The Theory and Practice, $4^{\text {th }}$ edition, London: Sage Publication.

Turkle, Sherry, 1995. Life on the Screen, Identity in the Age of the Internet, New York: Simon \& Schuster Paperbacks.

Global Internet Map, 2016. http://www.internetsociety.org/map/global-internet-report/, access November 10th 2016.

Social Media Statistics for Indonesia, 2016, http://socialmemos.com/social-media-statistics-for-indonesial, access November 10th, 2016. 